\title{
Left main bronchus separation after blunt trauma
}

\author{
Hanna Lisowska, Marek Marciniak, Konrad Pawełczyk \\ Thoracic Surgery Center, Lower Silesian Centre of Lung Diseases, Wrocław, Poland \\ Kardiochirurgia i Torakochirurgia Polska 2017; 14 (1): 71-75
}

\begin{abstract}
Tracheobronchial damage is very rare in clinical practice and represents no more than $1 \%$ of all injuries caused by blunt trauma. Nearly $80 \%$ of patients die before reaching the hospital. Most ruptures are observed in the right main bronchus and are located within $2 \mathrm{~cm}$ of the carina trachea. The highest mortality rate applies to patients with bilateral bronchial injuries. Nonspecific symptoms, additionally masked by complaints regarding other damaged organs, delay the diagnosis and surgical treatment. The aim of this article is to present one particular clinical case and to discuss it in conjunction with a literature review.
\end{abstract}

Key words: chest blunt trauma, tracheobronchial rupture, bronchial injuries, bronchial stenosis, bronchial resection.

\section{Introduction}

Chest injuries constitute barely $3-4 \%$ of the consequences of blunt trauma, whereas nearly $25 \%$ of posttraumatic deaths are caused by injuries to the chest. Such injuries are present in over half the patients after multifocal trauma. Statistically, airway trauma is most commonly observed among men under 40 years of age, and the malefemale ratio is $3: 1[1,2]$. Respiratory tract injuries constitute only $0.8 \%$ of blunt thoracic traumas [3]. The most common location is the right bronchial tree $-47 \%$ [4]; nearly $80 \%$ of injuries are located less than $2 \mathrm{~cm}$ from the carina [4]. Left-sided bronchial injuries constitute $32 \%$ of cases, while only $2 \%$ involve trauma to both main bronchi. The rate of post-traumatic tracheal ruptures is around 19\% [4]; they are most often located in the cervical trachea (1015\%) [5]. Most involve the cartilaginous part of the trachea (approx. 74\%), while 18\% involve its membranous wall [6].

The nonspecificity of the clinical symptoms, which often overlap with symptoms arising from other injured organs, results in diagnostic difficulties and delays the start of treatment. The symptom most often mentioned in clinical practice is subcutaneous emphysema; other frequently observed symptoms include dyspnea, changes of vocal

\section{Streszczenie}

Uszkodzenia dróg oddechowych są rzadkie w praktyce klinicznej i stanowią nie więcej niż 1\% obrażeń spowodowanych tępymi urazami. Blisko $80 \%$ pacjentów umiera przed dotarciem do szpitala. Uszkodzenia najczęściej stwierdza się w prawym oskrzelu głównym, większość zlokalizowana jest w odległości do $2 \mathrm{~cm}$ od ostrogi tchawicy. Największy wskaźnik śmiertelności dotyczy pacjentów z uszkodzeniem obejmującym oba oskrzela główne. Niespecyficzność objawów oraz ich maskowanie przez dolegliwości ze strony innych uszkodzonych narządów opóźniają ustalenie rozpoznania i leczenie chirurgiczne. Celem pracy jest przedstawienie przypadku pourazowego oderwania oskrzela głównego płuca lewego oraz jego omówienie w powiązaniu z usystematyzowaną wiedzą z piśmiennictwa.

Słowa kluczowe: tępy uraz klatki piersiowej, uszkodzenia tchawiczo-oskrzelowe, uszkodzenie oskrzela, zwężenie oskrzela, resekcja oskrzelowa.

timbre, hemoptysis, and bleeding (if the injury involves the bronchial arteries). Some respiratory tract injuries are asymptomatic. Imaging examinations reveal pneumothorax, sometimes bilateral. Increased air leakage in the drainage system after the connection of a suction device to the pleural drain is an important symptom that suggests the possibility of airway disruption [7]. In the case of injuries located in the thoracic part of the respiratory tract, mediastinal emphysema with the accumulation of air in the subcutaneous tissue may be the only symptom present [7].

When airway injury is suspected, the primary diagnostic examination is bronchofiberoscopy, which also enables the assessment of the extent of the injury. In the case of intensified bleeding, classic rigid bronchoscopy is recommended [7].

\section{Case report}

The patient was a 25-year-old male mine worker, who suffered a multiorgan injury when he was buried by falling rocks. On admission to the Intensive Care Unit, he was in a severe condition and exhibited symptoms of cardiopulmonary failure. The patient was intubated - mechanical ventilation was introduced along with pharmacological

Address for correspondence: Hanna Lisowska MD, Thoracic Surgery Center, Lower Silesian Centre of Lung Diseases, 105 Grabiszyńska St, 53-439 Wrocław, Poland, phone: +48 7915676 35, e-mail: vea16@interia.pl

Received: 3.08.2015, accepted: 12.12.2016. 
therapy with catecholamines and antibiotics. After a chest radiogram revealed right-sided pneumothorax and costal fractures (ribs $I-V$ ), a drain was introduced into the right pleura. The patient's crushed right foot was treated surgically (amputation at Chopart's joint), while the fractured medial condyle of the femur was treated conservatively. Due to the observed incidents of reduced respiratory fitness parameters, computed tomography of the chest was performed on the $3^{\text {rd }}$ day after the trauma. The examination visualized irregularities in the outline of the left main bronchus and a consolidation of gas bubbles in this area, which prompted the suspicion of bronchial injury (Figures 1 A, B, 2 A, B present a tomographic reconstruction of the respiratory tract).

Diagnostic investigation was supplemented with bronchofiberoscopic examination, revealing hyperemia and massive edema of the mucosa in the proximal segment of the left main bronchus, immediately next to the tracheal bifurcation. Consequently, the attempt to reach the left main bronchus with the endoscope was unsuccessful.

The patient was referred for further treatment at the Thoracic Surgery Center in Wrocław with a suspicion of airway disruption. A decision was made to perform urgent surgical treatment. Left posterolateral thoracotomy was performed. Typical post-traumatic lesions were found intraoperatively: a pleural hematoma (approx. $500 \mathrm{ml}$ in volume) and extensive hematomas in the tissues of the thoracic integuments. A small amount of air was found in the mediastinum. Prepare of the mediastinal tissues revealed the completely amputated left main bronchus; the whole length of the membranous part of the bronchus was ruptured. The bronchial membrane was sutured longitudinally. Subsequently the detached bronchus was anastomosed
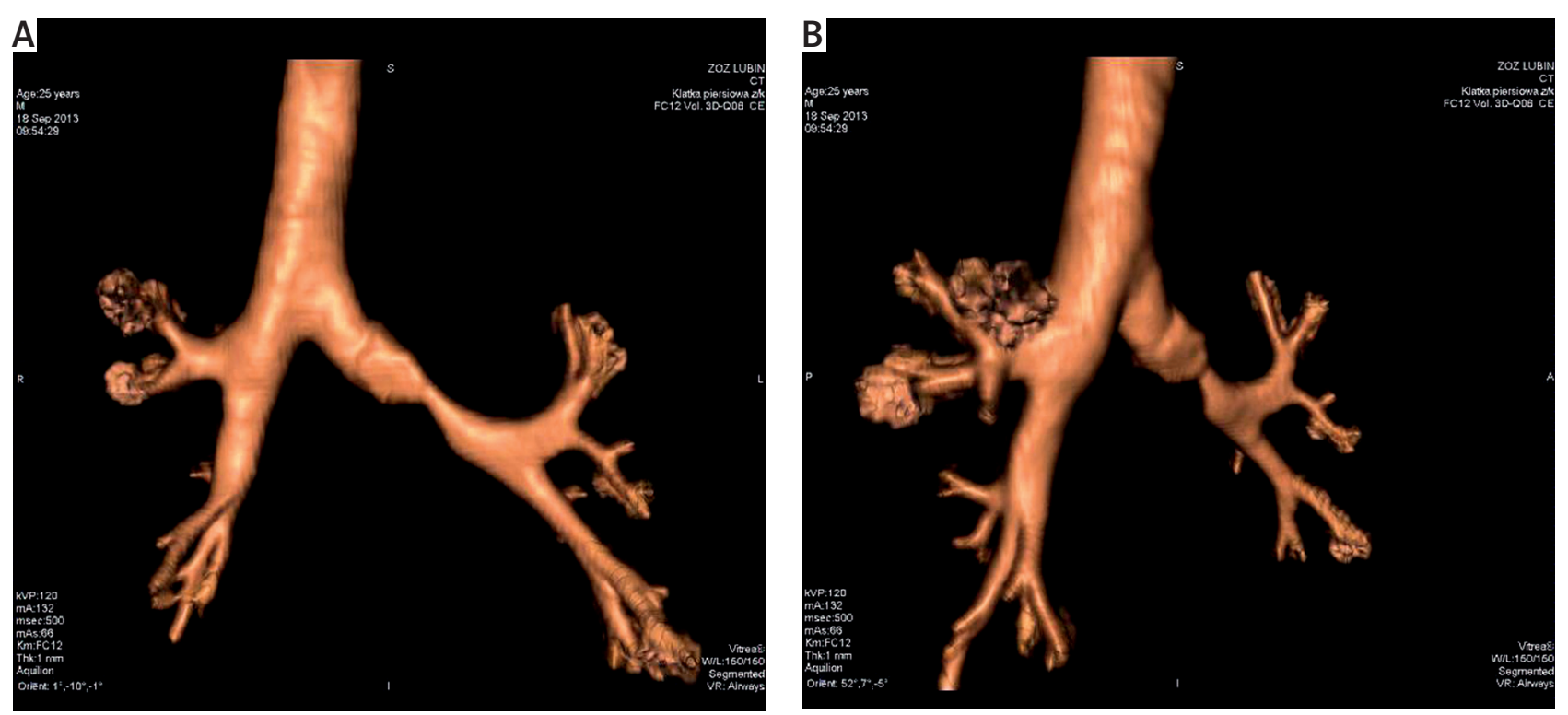

Fig. 1 A, B. Tomographic image reconstructions: deformation of the wall of the left main bronchus
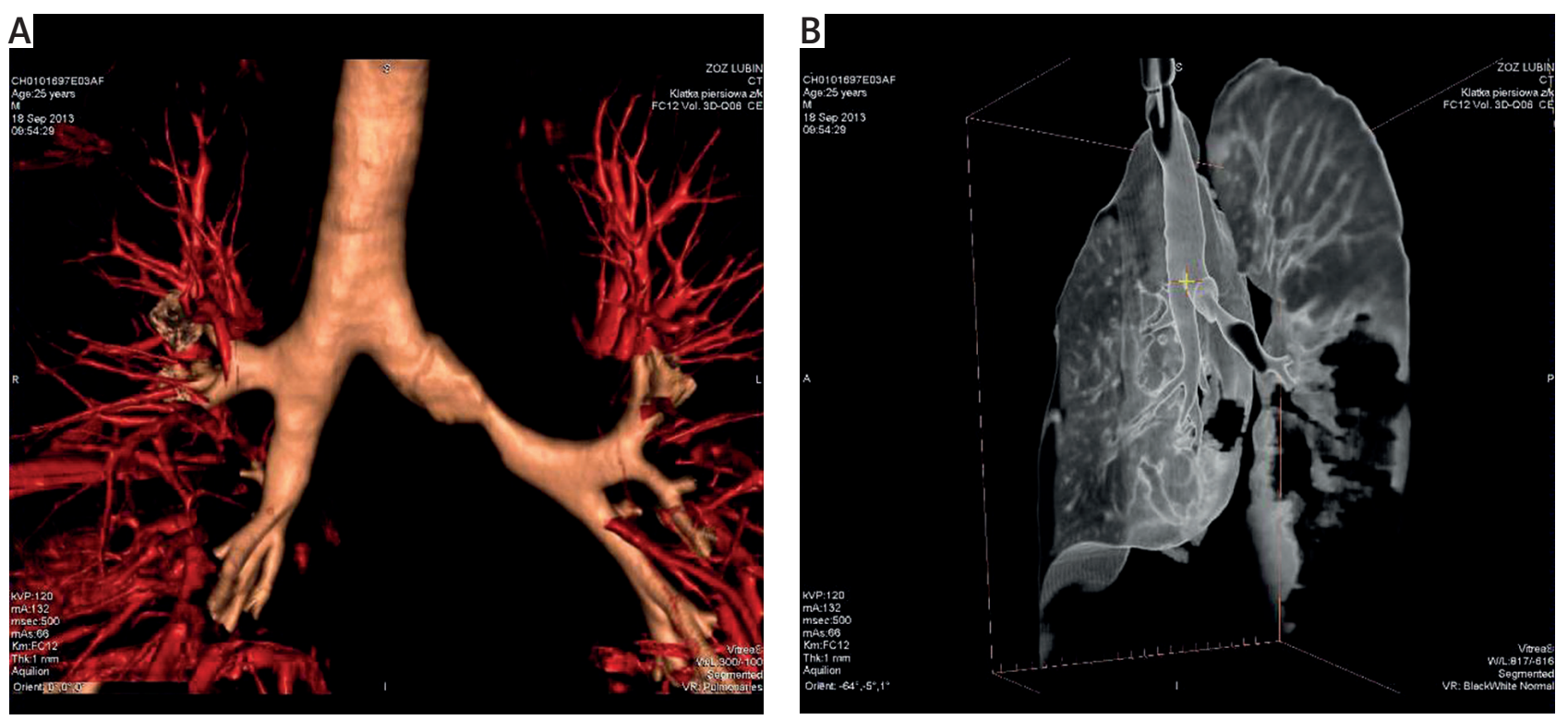

Fig. 2 A, B. Tomographic image reconstructions: vascular system and lung parenchyma 


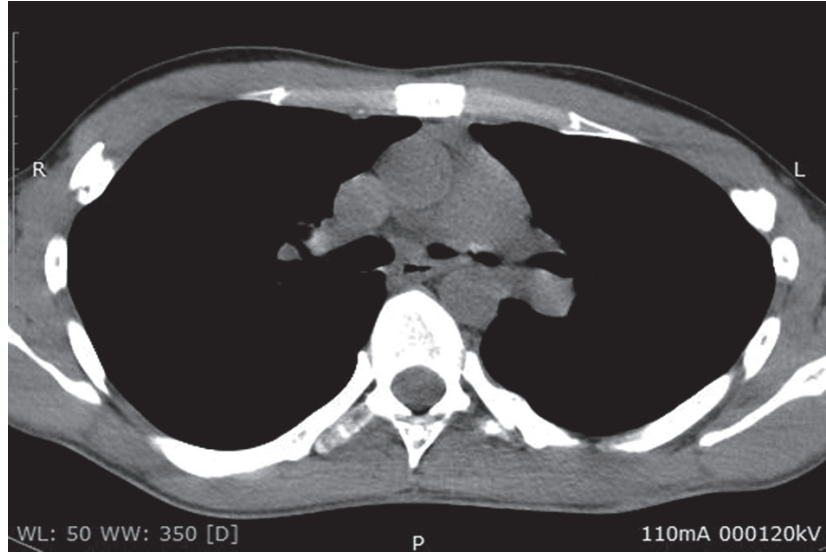

Fig. 3. Obturation of the left main bronchus at the anastomosis site

with the trachea, and the anastomosis was wrapped with an intercostal muscle flap.

The patient's hospitalization continued at the Intensive Care Unit of the Lower Silesian Lung Diseases Center. The dosage of catecholamines and sedatives was gradually reduced. On the $3^{\text {rd }}$ day, the drain from the left pleura was removed; 3 days later, the right pleural drain was removed as well. On the $6^{\text {th }}$ day after the thoracotomy, the airway was reevaluated with an endoscope, revealing stenosis at the tracheobronchial anastomosis; the endoscope could not pass through this location. Additionally, a large amount of mucous secretion, which filled the whole bronchial tree, was evacuated. A decision was made to wake and extubate the patient. Consequently, the secretion accumulated again, resulting in a repeated bronchoaspiration after less than $20 \mathrm{~h}$. It was deemed necessary to perform tracheotomy. After the patient's cardiopulmonary parameters stabilized on the $14^{\text {th }}$ postoperative day, the patient was referred for further treatment on the Thoracic Surgery Department. The treatment consisted in rehabilitation and fitness improvement. The patient was discharged from the Center on the $18^{\text {th }}$ postoperative day. After less than 6 weeks, the patient was readmitted with symptoms of left main bronchus occlusion. For the past several days, the patient had manifested symptoms of airway infection: he was fever and he had dyspnea. An out-patient computed tomography (CT) scan demonstrated anastomotic stenosis (Fig. 3), but lung aeration was maintained (Fig. 4).

A chest radiogram (Fig. 5) taken on the day of readmission (7 days after the CT exam) revealed complete atelectasis of the left lung.

Bronchofiberoscopic examination showed that the lumen of the left main bronchus was very narrow: its diameter did not exceed $3 \mathrm{~mm}$. An attempt was made to perform mechanical dilatation, but without success.

The diagnostic investigation was supplemented with chest $\mathrm{CT}$, revealing obturation of the left bronchial tree (Fig. 6) and a complete lung atelectasis (Figs. 7-9).

A decision was made to perform surgical intervention. Thoracotomy was repeated with sleeve resection of the

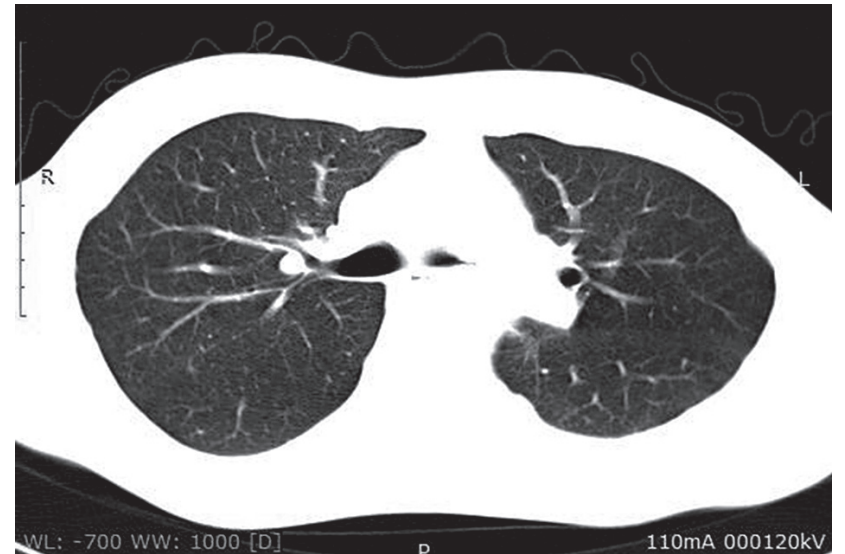

Fig. 4. Obstruction of the left bronchial tree with preserved lung aeration

stenosed left main bronchus (length: 1-1.5 cm), and the bronchus was anastomosed with the trachea (the posterior wall with single sutures, and the anterior wall with a continuous suture). Figure 9 shows the chest radiogram obtained on the $1^{\text {st }}$ postoperative day, while Figure 10 presents a radiogram from the $6^{\text {th }}$ postoperative day.

From the day of readmission, the patient was administered broad-spectrum antibiotic treatment. On the third postoperative day, the drain placed in the left pleura was removed. The patient was discharged on the $7^{\text {th }}$ postoperative day. He continued to be monitored as an outpatient - he attended follow-up visits, during which the site of anastomosis was evaluated with an endoscope. The first such examination took place 2 weeks after discharge, demonstrating permeability of the anastomotic site and no signs of inflammation. Subsequent follow-up examinations took place every three months until the end of February, 2015. The final examination showed a stable endoscopic image with satisfactory width of the left main bronchial lumen.

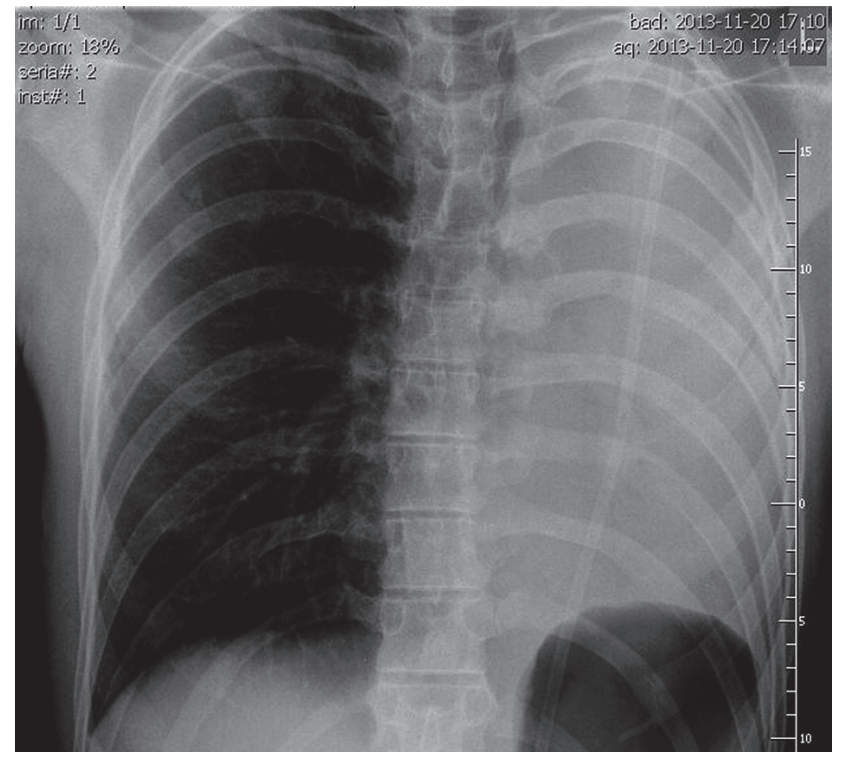

Fig. 5. Radiological image of left lung atelectasis 


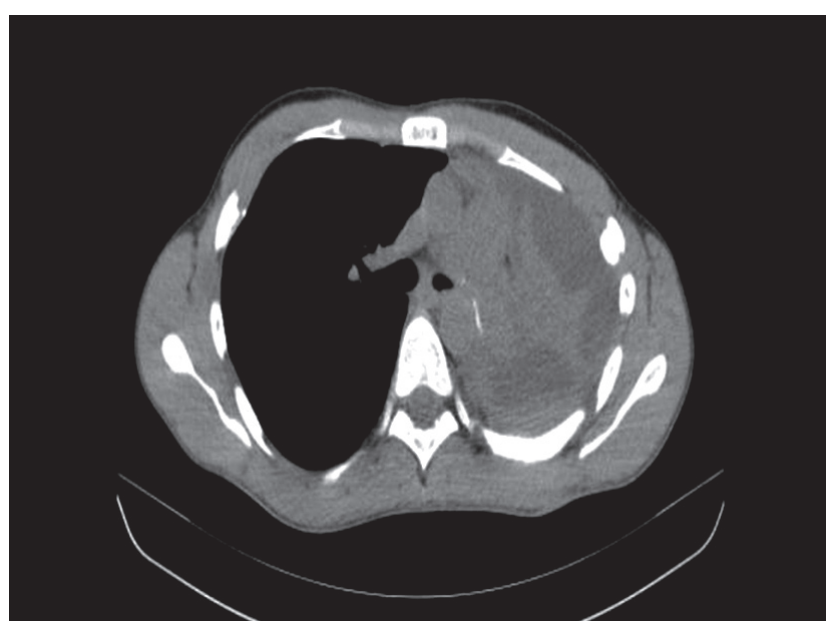

Fig. 6. Computed tomography image: obstruction of the left bronchial tree
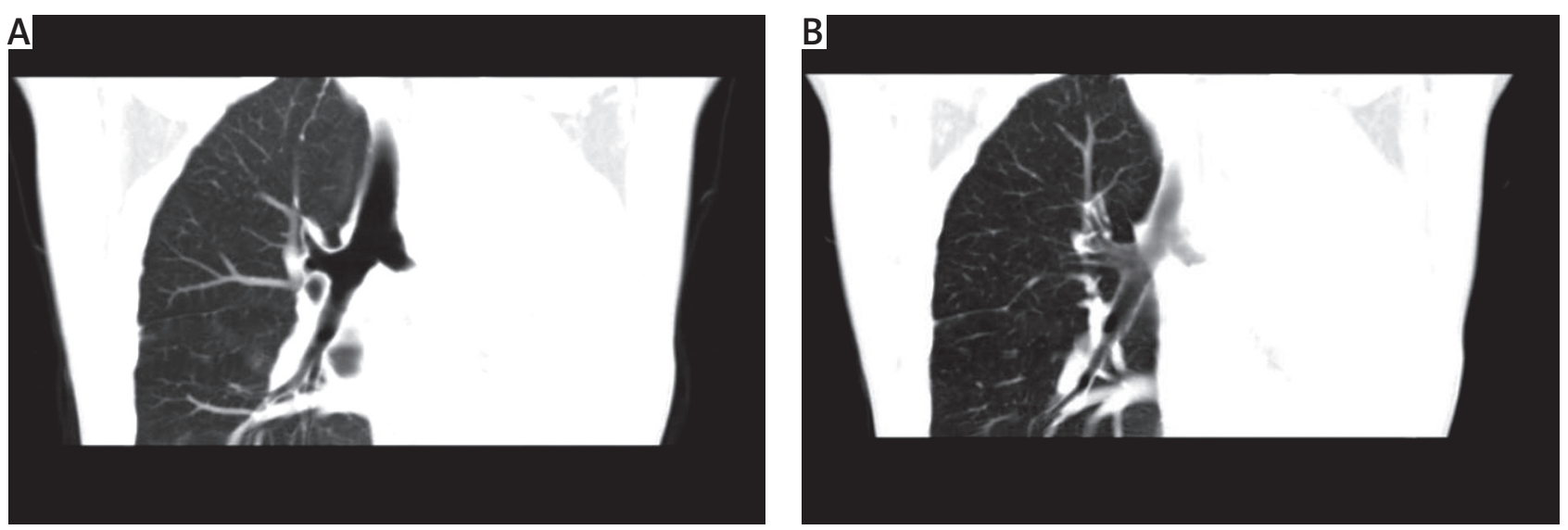

Fig. 8. Chest computed tomography: bronchographic reconstruction scans

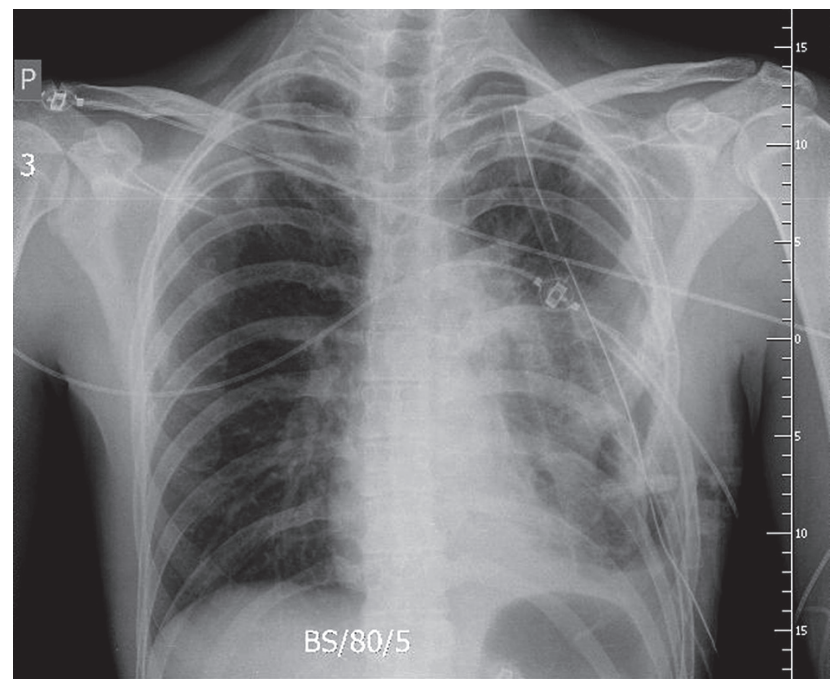

Fig. 9. First postoperative day

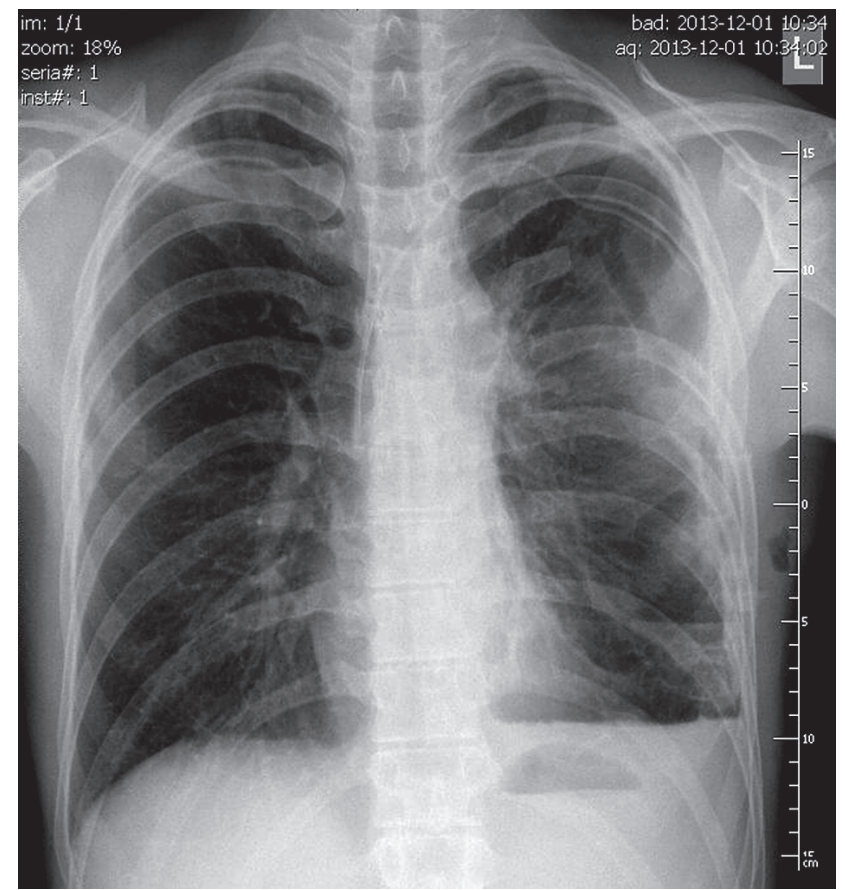

Fig. 10. Chest X-ray from the day preceding the patient's discharge 


\section{Discussion}

Post-traumatic airway injuries are very rare in clinical practice. Due to the character and multifocality of the traumatizing force, symptoms of other organs are often much more pronounced and mask the symptoms related to the respiratory system. The nonspecificity of the symptoms results in additional diagnostic difficulties.

The mortality rate is $60 \%$ for bilateral bronchial damage, $26 \%$ for tracheal injuries, and, respectively, 16\% and $8 \%$ for isolated injuries of the right and the left bronchial tree [4]. Statistically, the median time until diagnosis is estimated at approximately 9 days, and until the start of surgical treatment at 25 days. The median time until diagnosis and treatment is, respectively, 30 and 42 days for left-sided bronchial injuries, 1 and 3 days for right-sided injuries, and 3 and 23 days for tracheal injuries [4].

The type, extent, and possible consequences of a blunt trauma are determined by 3 factors: compression, truncation, and shock wave. Elasticity of the affected tissues is also significant. In the case of slow deformation, the energy is dispersed as the tissues buckle under compression; if the deformation is too quick, the tissues are ruptured. The literature features three theories explaining the mechanism of airway injury. The first one assumes that the action of a violent compression force in the anteroposterior dimension results in its transverse dispersion. Consequently, the pulmonary parenchyma is pressed against the chest wall, and the lateral forces cause the lung to press on the tracheal bifurcation. This is presumably the dominant mechanism for crushing injuries. According to the second theory, confirmed in experimental canine studies, the rising compression of the chest and trachea with a closed glottis leads to a rapid increase of airway pressure (especially in the trachea and large bronchi). When the respiratory tract's elasticity is overcome, a rupture occurs (usually of the membranous part). The third theory assumes that during quick deceleration the force disperses, resulting in traumatization of the trachea and the bronchial tree. This mechanism best explains the injuries occurring in traffic accident victims $[8,9]$.

Injuries of the left bronchial tree are observed less frequently; this is due to the close proximity of the aortic arch, which stabilizes the bronchus. The force injuring the bronchus simultaneously causes a rupture of the aortic wall, which most often results death on the scene [7]. In the present case, the traumatic mechanism was probably somewhat different, as evidenced by the CT image and the intraoperative situation. The dynamism of the traumatic process was surprising in the context of the relatively inconspicuous clinical manifestation. The lack of sleeve resection of the injured bronchus during the first procedure is worth discussing. The decision was made in view of the patient's severe condition including cardiopulmonary failure, the impossibility of making technical provide for the anesthesiological and surgical team, and the intraoperative surprise factor. The literature features recommenda- tions stating that reconstruction should be attempted in the case of bronchial injuries located proximally to the subsegmental branches, while the distal segments should be resected [10].

The survival rates of patients treated with surgery are better than those of patients treated conservatively. The mortality rate is lower in patients in whom bronchial reconstruction was performed than in patients in whom the injured bronchial segment was resected with the peripheral fragment of pulmonary parenchyma ( $3 \%$ vs. $13 \%$ ). In the case of tracheal injuries, the mortality rate was estimated at $6 \%$ in patients treated with surgery and $66 \%$ in patients treated conservatively [4].

The present case raises the question whether covering the anastomotic site with a pedicled intercostal muscle contributed to the occurrence of stenosis [11]. Recommendations that can be found in the medical literature include the use of reversed parietal pleural flaps, pericardial fat, or fragments of the serratus anterior, pectoralis major, or latissimus dorsi muscle [7]. In the long term, intercostal muscles show a tendency to calcify $[7,11]$, as was the case in the present patient -9 weeks passed between the first and the second procedure. Another question open for discussion is the possibility of dilatation the lumen of the stenosed bronchus with a laser. However, in view of complete lung atelectasis, the symptoms of infection, and the young age of the patient, a decision was made to perform surgical treatment.

This case study was presented at the Extended Conference of the Polish Thoracic Surgeon Club (March 20-21, 2015 in Karpacz).

\section{Disclosure}

Authors report no conflict of interest.

\section{References}

1. Salem AM, Brik A, Refat A, Elfagharany K, Badr A. Is primary repair of tracheobronchial rupture curative? Open J Thorac Surg 2013; 3: 47-50.

2. Hartley C, Morritt GN. Bronchial rupture secondary to blunt chest trauma. Thorax 1993; 48: 183-184.

3. Jones KW. Thoracic trauma. Surg Clin North Am 1980; 60: 957-981.

4. Kiser AC, O’Brien SM, Detterbeck FC. Blunt tracheobronchial injuries: treatment and outcomes. Ann Thorac Surg 2001; 71: 2059-2065.

5. Roxburgh JC. Rupture of the tracheobronchial tree. Thorax 1987; 42: 681-688.

6. Kozak J, Łochowski M. Przypadek urazowego oderwania oskrzela płata środkowego. Pneumol Alergol Pol 2000; 68: 451-454.

7. Urazy klatki piersiowej. Kołodziej J. (Ed.). PZWL, Warsaw 2004.

8. Kirsh MM, Orringer MB, Behrendt DM, Sloan H. Management of tracheobronchial disruption secondary to nonpenetrating trauma. Ann Thorac Surg 1976; 22: 93-101.

9. Estridge CE, Hughes FA Jr, Pate JW, Cole F, Richardson R. Tracheobronchial injury caused by blunt trauma. Am Rev Respir Dis 1970; 101: 230-237.

10. Davari HR, Malekhossini SA. Managment of tracheobronchial injury: case presentation and review of the literature. Acta Med Iran 2005; 43: 291-298.

11. Gladish GW, Rice DC, Sabloff BS, Truong MT, Marom EM, Munden RF. Pedicle muscle flaps in intrathoracic cancer resection: imaging appearance and evolution. Radiographics 2007; 27: 975-987. 